3) R. L. Bieleski, N. A. Turner : Anal. Biochem., 17, 278 (1966).

4) S. Katz, A. Lewis : ibid., 17, 300 (1966).

5) 五島文韶, 横山香寿子 : 本誌, 18, 1493 (1969).

6) 武者宗一郎, 越智 紘 : 同上, 14, 728 (1965).

$$
\grave{n}
$$

Thin-layer electrophoresis of amino acids on Japanese acid clay. Fumiaki Goshima and Yuriko Ghinaya (Faculty of Education, Gifu University, Nagara, Gifu-shi)

The separation of seven neutral amino acids by thin-layer electrophoresis on Japanese acid clay (JAC) has been described.

Glass plates $(3 \times 17 \times 0.2 \mathrm{~cm})$ were coated with a throughly mixed slurry of $40 \mathrm{~g}$ of JAC (Nakarai Chemicals, Kyoto Japan) in $75 \mathrm{ml}$ of $1 \%$ sodium salt of carboxymethyl cellulose to $0.5 \mathrm{~mm}$ thickness and air-dried overnight before use. Five microliters of amino acid mixture was applied on a point $4 \mathrm{~cm}$ from the plate-end, and a d.c. potential of 720 volts was applied for 60 minutes through the plate saturated with $0.1 \mathrm{~N}$ acetic acid.

The plate was dried in an oven at $100 \sim 110^{\circ} \mathrm{C}$ for 5 minutes, and then a solution of $0.5 \%$ ninhydrin in 95\% ethanol was sprayed. The spots of amino acids appeared after heating at $100 \sim 110^{\circ} \mathrm{C}$ for 10 minutes.

A mixture of cystine tryptophan, proline, phenylalanine, tyrosine, leucine and serine was separated on a single layer.

Tryptophan gave a violet spot by heating the plate before spraying the ninhydrin solution, and this reaction was specific and was not interfered from other amino acids.

(Received Nov. 4, 1969)

\title{
差動走査熱量法および示差熱分析法のサーモグラムに及ぼす 水酸化マグネシウムの結晶粒子の大きさの影響*
}

\author{
橋詰 源蔵， 網田 佳代子**
}

(1969 年 11 月 6 日受理)

\begin{abstract}
結晶粒子の大きさが熱分析に及ぼす影響について，試料として水酸化マグネシウムを用い，示差熱分 析装置, 差動走査熱量計を使って検討した。

電子顕微鏡，電子線回折，X線回折，表面積測定により，試料として用いた水酸化マグネシウムがひ ずみの少ない，表面のかなりきれいな単結晶粒子であることを確かめた。

サーモグラムのピーク立ち上がり温度（分解反応開始温度）は示差熱分析法, 差動走査熱量法ともに 結晶粒子の大きさに依存しない。ピーク頂点温度と粒子の大きさとの間には，特に差動走査熱量法に交 いて指数関係が存在した.

ピーク面積については，示差熱分析法では希釈して充てえ効果を除くと必ずしも結晶粒子の大きさ順 之は一致しない。差動走査熱量法では粒子の表面積との間に直線関係が存在することを認めた。
\end{abstract}

\section{1 緒言}

熱分析法のうちでよく用いられている示差熱分析（以 下DTA と略記）を行なう場合，分析結果に影暨を及ぼ 䒠因子として，装置，測定条件，試料の状態などがあ る.たとえば，試料粒子の大きさとその分布が熱分析に

* 差動走查熱量法, 示差熱分析法および熱重量分析法 による工業分析法の研究 (第 2 報). 第 1 報は橋詰 源蔵，網田佳代子：本誌，18，838 (1969)

**兵庫県立工業試験場 : 神戸市須磨区行平町 3 丁目
及ぼす影響についての Speil1)，Norton²)などの報告は 相反する結果を得ている。これは DTA 法の測定条件の 統一が困難なことを意味している。したがって DTA 法 による定量分析では，データの誤差が 10\% 前後であれ ばよいといわれている。

最近急速に発展してきた差動走査熱量計（以下 DSG と略記） は多数の成書に紹介され，また著者らも前報 に述べたように，その測定誤差は 2〜3\% 以下でピーク 面積は熱量にかなりよく比例する。

著者らは粒子の大きさが熱分析結果に及ぼす影響につ 
いて，かなりき机いな単結晶粒子の水酸化マグネシウム について, DSCにより検討し，DTA による結果と比 較した。

$$
2 \text { 実験 }
$$

\section{$2 \cdot 1$ 試 料}

試料と乙て用いた結晶粒子の大きさの異なる水酸化マ グネシウムは，著者ら4)尔前に酸化マグネシウムの性質 について検討したと同じ方法で製造した。粒子の大きさ の異なる水酸化マグネシウム家つくる他の方法として, 異なる塩の水溶液反応などがある5)。著者らはこれらの

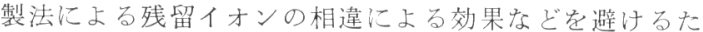
め，アース製薬社製の䘏基性炭酸マグネシウムを原料々 して用いた。塩基性炭酸マグネシウムを $400 \sim 900^{\circ} \mathrm{G} の$ 間の各温度で恒量（56.9\% 重量減少）になるまで加熱 分解し, 得られた酸化マグネシウムに脱炭酸した水在反 応させ，水酸化マグネシウムの沈殿をろ過したのち，乾 燥老早くするためにメチルアルコールとエチルエーテル を流しょく吸引したのち，炭酸ガスの吸収を避けるため に真空乾燥老行なった。な扮，生成した水酸化マグネシ
ウムはX線回折により酸化マグネシウムが存在しないこ と圭確かめた。

\section{$2 \cdot 2$ 水酸化マグネシウム結晶粒子の性状}

前述のように製造した水酸化マグネシウム絬晶粘子の 性状を，電子顕微鏡，X線回折装置，ソープトメーター を用いて测定した。

電子顥微鏡は日本電子(株)製进用いた．Fig. 1 亿塩基 性炭酸マグネシウムを $600^{\circ} \mathrm{C} ， 900^{\circ} \mathrm{C}$ で加熱分解した 酸化マグネシウムおよびそれふら得られた水酸化マグネ シウムの電子顕微鏡写真を示す.Fig. 1 より明らかなよ らに，塩基性炭酸マグネシウムの加熱温度が高い汪らが 酸化マグネシウムの結晶粒子が成長し, 水酸化マグネシ ウム粒子の大きさ海酸化マグネシウムの大きさに依存卞 る。 また写真の黑化度の違いから, 粒子の厚さの増加が 認められる。

Fig. 2 に制限視野法による電子顕微鏡像と電子線回折
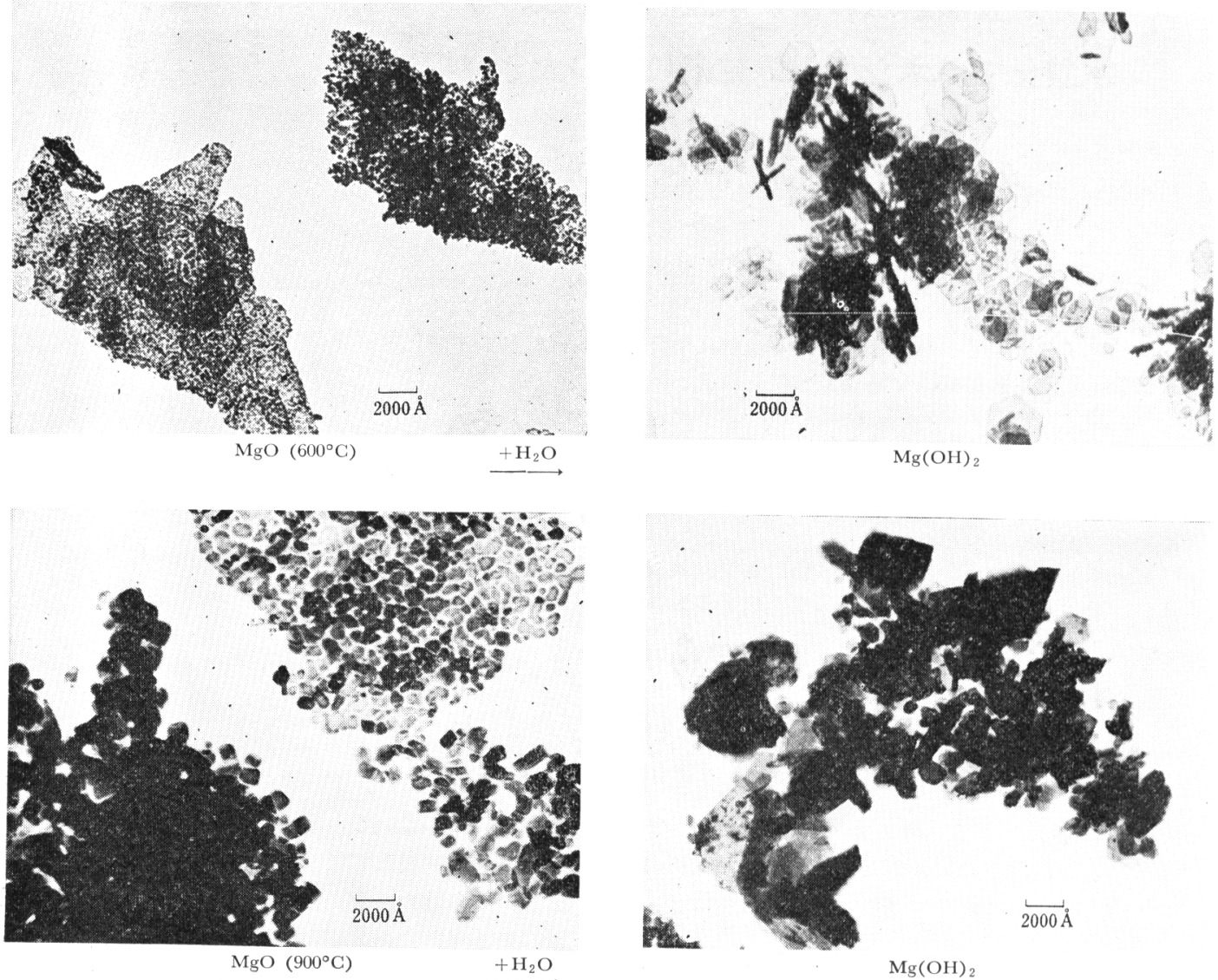

Fig. 1 Electron micrographs of magnesium oxide and magnesium hydroxide 


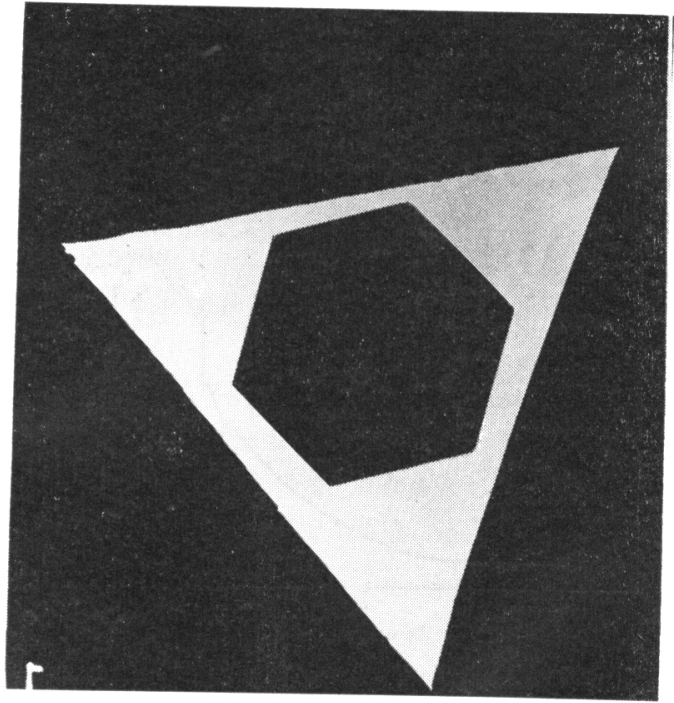

Electron micrograph

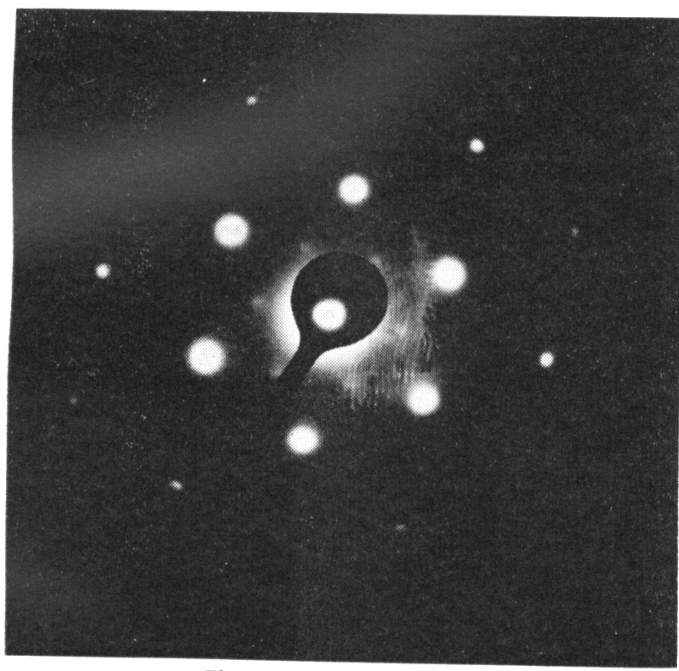

Electron diffraction pattern

Fig. 2 Electron micrograph and electron diffraction pattern by field limiting method of magnesium hydroxide
図形定示声・水酸化マグネシウム精子が六方晶のき机い な単結晶であることがわかる。

結晶粒子の大きさは, 理学電機(株)製のX線回折装置 老用いて測定した。ターゲットは銅，フィルターはニッ ケル它用いた。測定条件は走査速度：1/4, 1/8 $(2 \theta) /$ $\min$, 時定数 : $8 \mathrm{sec}$, 管電压: $40 \mathrm{kV}$, 記録紙速度 : 2 $\mathrm{cm} / \mathrm{min}$ とした。

Fig. 3 に酸化マグネシウムと水酸化マグネシウムのX 線回折図形走示殀. 回折線の半值幅の広がり注石英老用 いて得られた補正曲線军用いて求め, Scherrerの式によ って結晶子の大きさを算出した。回折線強度抢よび結晶 子の長さ, 厚さ走 Table I に示卞. Table I から明ら かなように原料の熱分解温度が高くなるにしたがい結晶 の厚さは長さに比べ著しく成長すること走している。

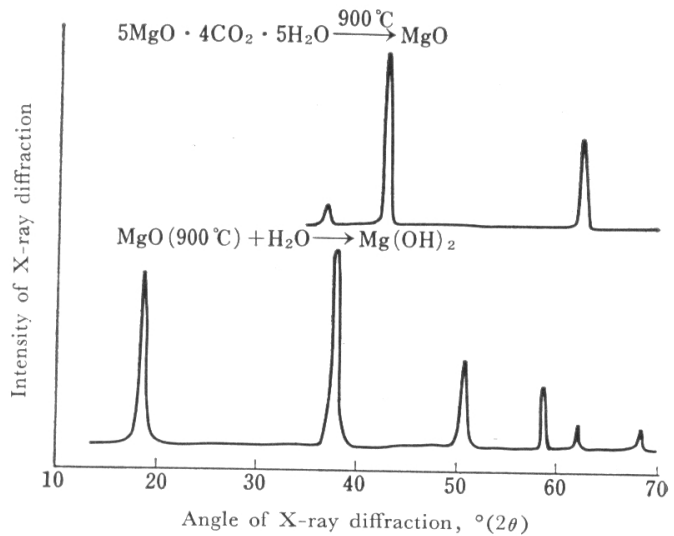

Fig. $3 \mathrm{X}$-ray diffraction pattern of $\mathrm{Mg}(\mathrm{OH})_{2}$ and $\mathrm{MgO}$

表面積はパーキンエルマー社製ソープトメーターを学用 い，BET の式により窒素の吸着量から求めた。 また别 にX線回折法で求めた結晶子の大きさ先用い, 水酸化マ グネシウムを正六角板状単結晶粒子，比重 2.39 と乙て 表面積学算出した。その結果も Table I に示した。 X

Table I Some characters of $\mathrm{Mg}(\mathrm{OH})_{2}$ prepared from $\mathrm{MgO}$ obtained by calcining $5 \mathrm{MgO} \cdot 4 \mathrm{CO}_{2} \cdot 5 \mathrm{H}_{2} \mathrm{O}$ at various temperature

\begin{tabular}{|c|c|c|c|c|c|c|c|}
\hline \multirow{2}{*}{$\begin{array}{c}\text { Temperature } \\
\text { calcining } \\
5 \mathrm{MgO} \cdot 4 \mathrm{CO}_{2} \cdot 5 \mathrm{H}_{2} \mathrm{O} \\
\left({ }^{\circ} \mathrm{C}\right)\end{array}$} & \multicolumn{3}{|c|}{ Diffraction intensity (Relative) } & \multicolumn{2}{|c|}{ Crystallite*size (A) } & \multicolumn{2}{|c|}{ Surface area $\left(\mathrm{m}^{2} / \mathrm{g}\right)$} \\
\hline & $I_{(001)}$ & $I(110)$ & $\begin{array}{l}I_{(110)} \\
I_{(001)}\end{array}$ & $D\left(\begin{array}{lll}0 & 1)\end{array}\right.$ & $D(110)$ & $\begin{array}{l}\text { By X-ray } \\
\text { diffraction }\end{array}$ & $\begin{array}{l}\text { By adsorption } \\
\text { of nitrogen }\end{array}$ \\
\hline 450 & 91 & 76 & 0.35 & 58 & 367 & 118 & 107 \\
\hline 500 & 100 & 90 & 0.38 & 106 & 480 & 74 & 86 \\
\hline 600 & 93 & 85 & 0.38 & 100 & 525 & 74 & 72 \\
\hline 650 & 95 & 93 & 0.41 & 202 & 822 & 41 & 50 \\
\hline 800 & 100 & 101 & 0.42 & 635 & 1550 & 17 & 14 \\
\hline 900 & 100 & 100 & 0.42 & 610 & 1380 & 19 & 21 \\
\hline
\end{tabular}


線回折法から求为た表面積の值上 BET 法より求的た值 はよく一致した。これらのこと方ら，試料の水酸化マグ ネシウム核細孔の少然い，かなりきれいな表面を持つ単 結晶粒子である。

\subsection{DTA 法}

装置注理学電機(株)製自動記録式示差熱，熱重量同時 測定装置を用い，測定条件は示差感度： $\pm 25 \sim \pm 250$ $\mu \mathrm{V}$ ，昇温速度 : $5^{\circ} \mathrm{C} / \mathrm{min}$ ，記録紙速度 : $180 \mathrm{~mm} / \mathrm{h}$ ，試 料容器: 白金製直径 : $7 \mathrm{~mm}$, 深さ : $19 \mathrm{~mm}$, 試料量 : 約 $300 \mathrm{mg}$, 対照試料: 原料塩基性炭酸マグネシウムを $900^{\circ} \mathrm{C}$ 以上で分解させて生成した酸化マグネシウムを 用いた，水酸化マグネシウム試料のかさが異なるため, 対照試料として用いた酸化マグネシウムと水酸化マグ ネシウムを $1: 1,3: 1,7: 1,15: 1,31: 1,63: 1$ の 割合で混合し，希釈効果について検討した。

ピーク面積は DTA 法, DSC 法ともにピークにそっ て切り拔いた紙の重量より測定した。

\subsection{DSG 法}

装置はパーキンエルマー社製を用い，測定条件流昇温

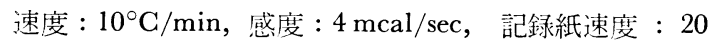
$\mathrm{mm} / \mathrm{min}$, 窒素気流中でアルミ製オープンサンプルパン を用いた。

試料量とピーク面積の関係を Fig. 4 亿示す。試料量 とピーク面積注直線関係を示す. 相対標準偏差注 $3 \%$ 以 下である。一般に DSC 法では試料量 $30 \mathrm{mg}$ 程度まで

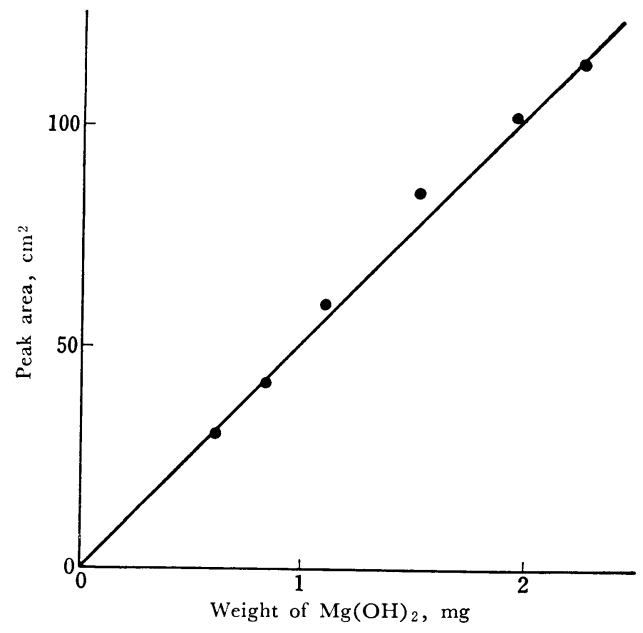

Fig. 4 Curve of peak area with DSC vs. weight of $\mathrm{Mg}(\mathrm{OH})_{2}$

Heating rate $: 10^{\circ} \mathrm{C} / \mathrm{min}$; Atmosphere $: \mathrm{N}_{2}$
はピーク面積と直線関倸が存在するが，本実験において 注，試料が多い場合分解ガスの影響で Fig. 5 亿見られ るようにサーモグラムに乱㞦を生じ，ピーク面積の測定 忍困難なため，試料量は約 $2 \mathrm{mg}$ とした。

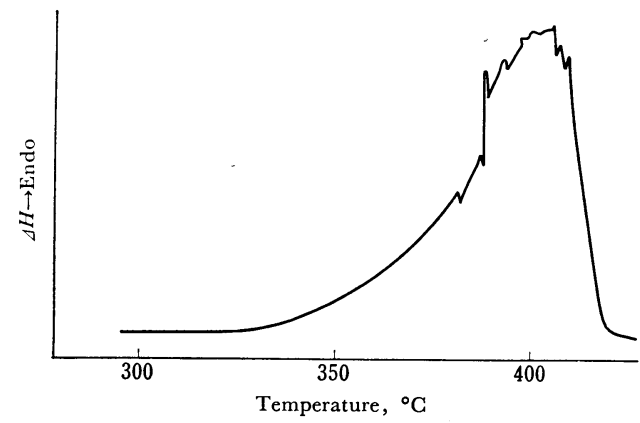

Fig. 5 DSC thermogram of a large amount of $\mathrm{Mg}(\mathrm{OH})_{2}$

Heating rate $: 10^{\circ} \mathrm{C} / \mathrm{min} ;$ Atmosphere $: \mathrm{N}_{2} ;$ Sample weight : About $10 \mathrm{mg}$

\section{3 結果と考察}

\subsection{DTA 法}

DTA 曲線のピーク立ち上がり温度は結晶粒子の大き

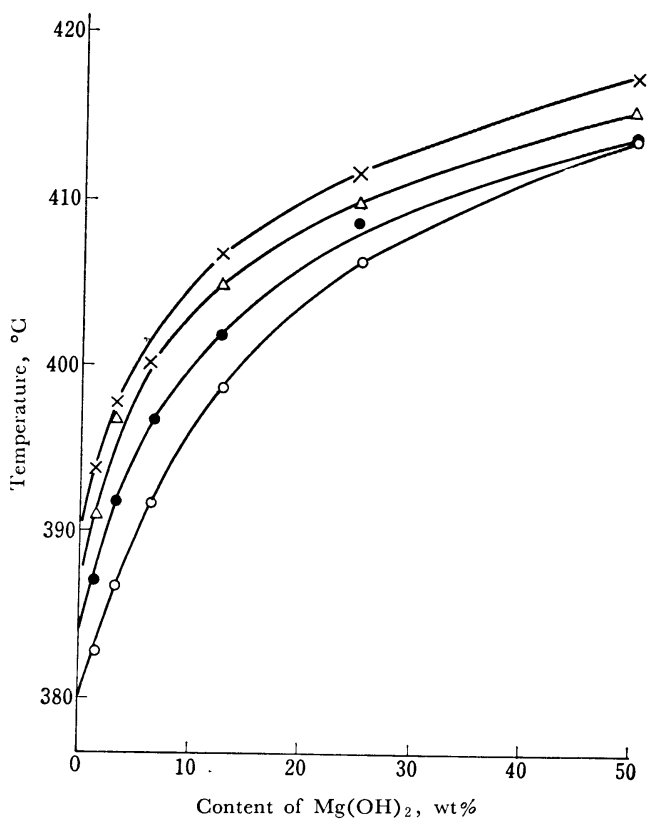

Fig. 6 Dilution effect on temperature of peak max. with DTA

Range : $50 \mu \mathrm{V} ; \quad$ Heating rate $: 5^{\circ} \mathrm{C} / \mathrm{min} ; \quad-\mathrm{O}-$ $450^{\circ} \mathrm{C} ;-500^{\circ} \mathrm{C} ;-\triangle-650^{\circ} \mathrm{C} ;-\times-800^{\circ} \mathrm{C}$ 
さに依存せず， $340 \pm 3^{\circ} \mathrm{C}$ であった。ピーク頂点温度 之結晶粒子の大きさ㧍よび希积効果汇ついての結果堂 Fig. 6 に示守. ピーク頂点温度は希釈割合の増加ととも に低温側へ移行し，結晶粒子が大きくなるにしたがって

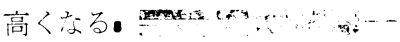

DTA曲線のピーク面積の結果を Fig. 7 亿示守，面 積济それぞれの希橎割合における面積を同一試料量に換 算した結果である。原料加熱温度 $800^{\circ} \mathrm{C}$ の試料泳さ 吢低く，希釈による充てえ効果沙少ないが，原料加熱温 度が低くなるにしたがい充てえ効果注大きく, 希釈度に よるピーク面積の変化が大きくなる。じゅうぶえに希积 された時点において，ピーク面積の変化法必ずしも結晶 粒子の大きさ順汇従っていないことが認められる.

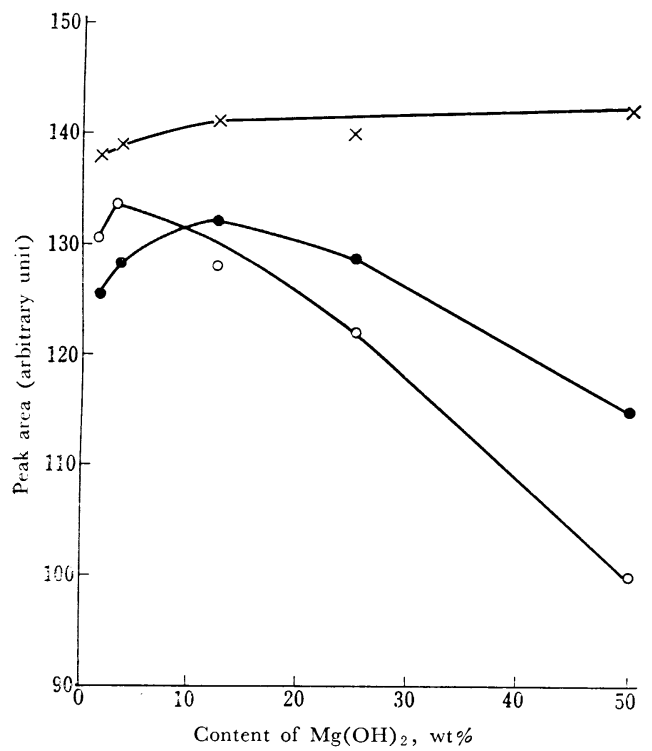

Fig. 7 Dilution effect on peak area of DTA

Range : $50 \mu \mathrm{V}$; Heating rate $: 5^{\circ} \mathrm{C} / \mathrm{min} ; \quad-\mathrm{O}-$ $450^{\circ} \mathrm{C} / \mathrm{min} ;-500^{\circ} \mathrm{C} / \mathrm{min} ;-\times-300^{\circ} \mathrm{C} / \mathrm{min}$

\subsection{DSC 法}

DSC 法から得たサーモグラムのピーク立ち上がり温 度は $327 \pm 3^{\circ} \mathrm{C}$ である.脱水分解開始温度が結晶粒子の 大きさによらないことは DTA 法と一致するが，昇温速 度, その他の条件が異なるため温度の相違*が認められ 万.

次にピーク頂点温度と粒子の長さの関係を Fig. 8 に

* 化学便覧では水酸化マグネシウムの分解温度は 350 ${ }^{\circ} \mathrm{C}$ と記載されているが, Anderson や他の報告》で は $247^{\circ} \mathrm{C}$ な゙の低い温度が認められ, 分解温度は 試料の作製法および測定法によって異なる.

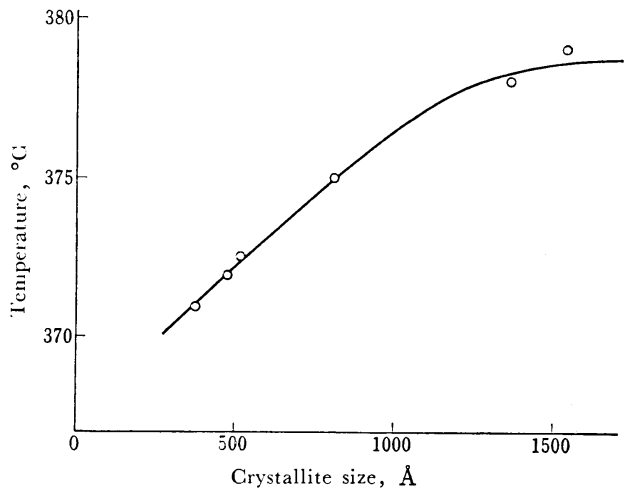

Fig. 8 Relation between crystallite size $\left(D_{(110)}\right)$ and temperature of peak maximum with DSC

Heating rate $: 10^{\circ} \mathrm{C} / \mathrm{min} ;$ Atmosphere $: \mathrm{N}_{2} ;$ Sample weight : About $2 \mathrm{mg}$

示す、結晶子の長さ上ピーク頂点温度の間に指数関係が 存在し, 脱水分解反応速度が結晶粒子の長さの影響を受 汀ること示し，DTA 法と同じ結果を示している。水 酸化マグネシウムの脱水分解反応が六方晶の層中を水が 2 次元拡散することによって進行すること注結晶学的に も当然である。またこのこと流 Anderson ら6)が TGA 忌用いた等温熱分解実験から証明している。

ピーク面積々試料の此表面積との関係を Fig. 9 亿 示す、ピーク面積注試料の表面積と直線関係にある. Vaivads $5^{6)}$ の報告に上る上塩基性炭酸マグネシウムを

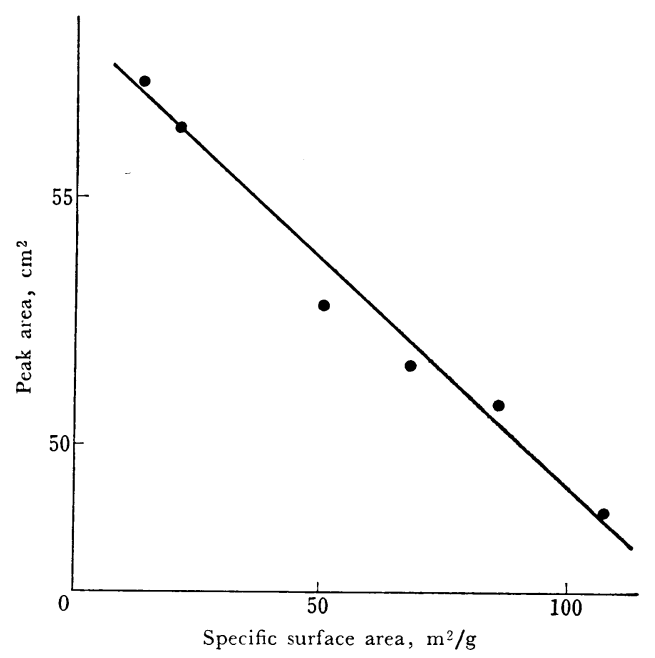

Fig. 9 Relation between specific surface area and peak area by DSC

Heating rate $: 10^{\circ} \mathrm{C} / \mathrm{min}$; Atmosphere $: \mathrm{N}_{2} ;$ Sample weight : About $2 \mathrm{mg}$ 
$300 \sim 1400^{\circ} \mathrm{C}$ の温度で処理して酸化マグネシウムを生 成した場合，塩基性炭酸マグネシウムを分解させた温度 が低いほざ酸化マグネシウムは活性であり，それらの酸 化マグネシウムを水和して得ら秃る水酸化マグネシウム 生成熱は 8.2 から $9.4 \mathrm{kcal} / \mathrm{mol}$ の異なる值であり, こ れは酸化マグネシウムの表面積の相違之構造欠陥が原因 である、著者らが用いた試料はほとえどひずみのない， 完全に近い単結晶であるから，ピーク面積（分解熱）の 差は表面積（結晶粒子の大きさ）に依存すると考えられ る. 結晶粒子の大きさによる分解エネルギーの違いを次 のように考える.すなわら，結晶エネルギーは結晶の表 面層よりも内部層において大きく，内部層と表面層との 占める割合により分解エネルギーが異なる．大きな結晶 粒子ほど分解エネルギーが大きくなり，すなわ它定量的 分析を行ならとピーク面積が大きくなるのであるう。

\section{4 結 論}

表面のかなりきれいなひずみの少ない単結晶に近い 粒子の大きさの異なる水酸化マグネシウム試料の熱分析 を行なうと，サーモグラムのピーク立ち上がり温度およ びピーク頂点温度は DTA 法，DSC 法ともに同じ傾向 を示し，分解開始温度は粒子の大きさに依存しないが， 分解速度は粒子の大きさの影響を受け，特にDSG では ピーク頂点温度と結晶粒子の長さとの間に指数関係があ ることを認めた。

またピーク面積については，DTA 法で注粒子の大き さ順の系統的な変化法認めら机ない。一方，DSC 法で は表面積と直線関係にあることが明らかになった。

以上のことから，DSCを用いて熱分析を行なう場合， 得られる結果は試料の大きさに依存し, 熱量測定の誤差 の原因になることが推察される・逆にこのように感度， 精度のよいDSCを使うことにより, 結晶状態について の知見を得られる可能性が存在すると思う.

終わりに，本研究において電子顕微鏡による測定に ご協力いただいた当試験場横山崇金属分析研究室長, DSC の使用を許可された竹内貞治化学部長ならびに横 山 督高分子研究室長に謝意を表す.

(昭和 44 年 4 月, 日本化学会符 22 年会において発表)

\section{交}

\section{献}

1) S. Speil, L. H. Berkelhamer, J. A. Pask, B.
Davis : U. S. Bur. Mines, Tech. Papers, 664 (1945).

2) F. H. Norton : J. Am. Ceram. Soc., 22, 541 (1939).

3) 橋詰源蔵, 網田佳代子 : 本誌, 18, 838 (1969).

4) 橋詰源蔵, 新井祥交, 石野通雄, 高嶋四郎 : 兵庫 県工業奨励館研究報告, 5 (1966).

5）白根文男，杉森敏郎，吉沢四郎，岡田辰三：工 化, 62, 956 (1959).

6) A. Vaivads, V. A. Vishnevskaya : Latrijas PSR Zinatnu Akad. Vestis, Kim. Ser., 643-50 (1965); Chem. Abstr., 64, 16717 (1966).

7) P.J. Anderson, R. F. Horlock : Trans. Faraday Soc., 58, 1993 (1962).

浜野健也：窯協，71，101（1963）.

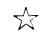

Effect of the particle size of crystalline magnesium hydroxide on differential scanning calorimetry and differential thermal analysis. (Studies on technical analytical methods by differential scanning calorimetry, differential thermal analysis and thermogravimetric analysis. II.) Genzo Hashizume and Kayoko Amita (Industrial Research, Institute, Hyogo-Pref., Suma-ku, Kobe-shi)

Magnesium hydroxides, $\mathrm{Mg}(\mathrm{OH})_{2}$, of various particle size were prepared by suspending magnesium oxide, $\mathrm{MgO}$, in the water free from $\mathrm{CO}_{2}$ at room temperature for a period enough to the hydration about a week. The $\mathrm{MgO}$ was obtained by heating basic magnesium carbonate $\left(5 \mathrm{MgO} \cdot 4 \mathrm{CO}_{2} \cdot 5 \mathrm{H}_{2} \mathrm{O}\right)$ at $400 \sim 900^{\circ} \mathrm{C}$.

The $\mathrm{Mg}(\mathrm{OH})_{2}$ was observed under an electron microscope and examined by electron diffraction by field limiting method. Consequently, it was recognized that each particle of $\mathrm{Mg}(\mathrm{OH})_{2}$ was a nearly perfect single crystal. The size of the crystallite and the crystallinity were determined by X-ray diffraction method. The surface area was measured by adsorption of nitrogen or by calculation from the size of crystallite, the values being in good agreement.

The temperature at which an endothermic peak on the thermogram in differential thermal analysis (DTA) and differential scanning calorimetry (DSG) starts is independent on the particle size of $\mathrm{Mg}(\mathrm{OH})_{2}$.

The maximum temperature of the peak rises exponentially with increasing size of the crystallite. The relation between the peak area of DTA and the particle size is not systematic, but the peak area in DSC decreases in inverse proportion to an increase of the surface area of $\mathrm{Mg}(\mathrm{OH})_{2}$.

(Received Nov. 6, 1969) 